\section{RAFT 法}

Rizzardo らのグループにより見い

だされた， $\mathrm{S}=\mathrm{C}(Z) \mathrm{S}-\mathrm{R}$ で表される連 鎖移動剤 (1) を添加することでリビングラジカル重合を 行う方法である. RAFT とは, Reversible AdditionFragmentation Chain Transfer の頭文字を取ったも の. (1)により, リビング重合を達成するには (1) が高 い反応性（大きな連鎖移動定数）を有し, 成長ラジカル $\left(\mathrm{P}_{n} \cdot\right)$ 招よび $\mathrm{P}_{n} \cdot$ と $(\mathbf{1})$ との反応により生じるドーマント 種 $\left(\mathrm{P}_{n}-\mathrm{S}-\mathrm{C}(\mathrm{Z}) \cdot-\mathrm{S}-\mathrm{R}\right)$ との速い平衡を保つことがポイン トである.このために，Zとしてはフェニルあるいはメ
チル基， $\mathrm{R}$ としてベンジルあるいはシアノイソプロビル 基など脱離しやすく再開始能力の高い置換基が選択され る.

この重合方法は安定ラジカルや遷移金属を用いるリビ ングラジカル重合法に比べて，通常のラジカル重合と変 わらない条件で重合可能で, アクリル酸エステル類, ス チレン類やアクリル酸など広範囲のモノマーに適用でき るという特徴がある．さらに，ブロック共重合体や， R に官能基を導入して末端官能基化ポリマーの合成屯可能 である。

[509 頁］岡野 善道

\section{-ファーター例えば, ベンジル $N, N$-ジェ チルジチオカルバマート $(\mathrm{R}-\mathrm{X})$} は光照射によりホモリシスを起こして, ベンジルラジカ ル $(\mathrm{R} \cdot)$ とジェチルチオカルバマート硫黄ラジカル $(\mathrm{X} \cdot)$ を生じるが， R・ラジカルは重合を開始するものの X·ラ ジカルは比較的安定で，ポリマーラジカル P.を捕捉し て（P.と停止反応を起こして） 付加体 $\mathrm{P}-\mathrm{X}$ を生じると 考えられる.このとき，P-X結合がホモリシスや連 鎖移動反応で再び切れるなら，P・ラジカルが
再生され，成長反応が継続するであろう。このように， 開始剤 (initiator)，連鎖移動剤 (transfer agent), 停止 剂 (terminator) の 3 機能を併せもつ低分子または高分 子化合物をイニファータ (iniferter) と呼ぶ. 大津らは, 1982 年にイニファータによる重合をリビングラジカル 重合の具体的なモデルとして初めて提案したが，このモ デルは現在知られているリビングラジカル重合の主要 3 機構の中の 2 機構を含む.

\title{
定序性情䢁
}

さまざまな要素を 組み合わせて配列順

[499 頁] 福田猛

序をもたせたものが定序性（シーケンス）と呼

ばれ，これに基づく情報が定序性情報である，例

述のタンパク質や核酸であり，さらに糖やステ えば，0と 1 との組合せでコンピュータ，あいうえ

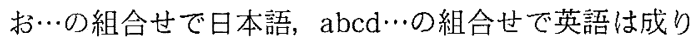
立つ.では, 分子の場合はどうか. 生物では, 20 種類 のアミノ酸を用いてタンパク質が， 4 種類のヌクレオチ ドを用いて核酸がつくられる，しかし分子の立場から考 えれば，これらの生体高分子は一例にしか過ぎないので はないか，炭素を主に考えれば，当然置換メチレン $\left(-\mathrm{CR}_{1} \mathrm{R}_{2}-\right)$ が基本となる．これが並んだキラル炭素の鎖 な情報物質をつくれるはずである，次の問題は，定序性 情報の表現であり，そのために非共有結合をいかに巧み に使いこなすかである，表現の例としては，生体高分子 の折りたたみにとどまらず，オリゴ糖やステロイドなど の中分子の分子集合や結晶構造，さらに超分子の立体構 造や包接化合物などがすぐに思いつくであろう.

[493 頁] 宮田 幹二

\section{厉䚮起子キラリティー法 \\ 光学活性有機化合} 円二色性 (CD) スペクトルから非経験的に決定する方法 である. 例えば, 光学活性な 1,2-ジオールのジベンゾ エート誘導体の CD スペクトルは二つのベンゾェート発 色団の励起状態での相互作用によって互いに反対符号の CD Cotton 効果（分裂型 Cotton 効果）を与える. 長 波長側の第一 Cotton効果が正で短波長側の第二 Cotton 効果が負の場合には正のキラリティーといい, 1,2-ジオールの C-C 軸に対して，二つのベンゾェート 基は手前から向こう側へ時計回りの牥じれが生じている.
第一 Cotton 効果が負で第二 Cotton 効果が正の場合に は負のキラリティーであり，二つの発色団は反時計回り のねじれをむつ．このようにCD スペクトルから二つの ベンゾェート発色団の絶対配置を読みとることができる. この方法は 1,2-ジベンゾェート系に限らず，一般に強 い $\pi \rightarrow \pi^{*}$ 吸収帯をむつ二つの等価な発色団が不斉の位 置に存在し，それらが励起子相互作用する光学活性化合 物に適用でき，高分子鎖の立体配置に起因するキラリ ティーの絶対構造の決定にむ応用可能である.

[504 頁] 横田 和明 